\section{On The Trail of the Fathers: The Serendipitous Santos}

\author{
Harry A. Alden* and Alvaro E. Galvis** \\ *Smithsonian Center for Materials Research and Education \\ * San Francisco State University \\ aldenh@scmre.si.edu
}

\section{Introduction}

I am a botanist, with an expertise in plant anatomy, specifically wood anatomy. In my capacity of microscopist for the Smithsonian Institution, I help answer research questions developed by curators, conservators, anthropologists and archaeologists. I am typically presented with a variety of materials that range from large, entire objects from museums to small, deteriorated, fragmentary samples from archaeological digs. Many of the requests center around the questions "What is it?" and "Where did it come from?" The answers to these questions help determine the traditional materials used by a culture and the distribution of these objects through trade and cultural exchange. Of the numerous requests that I receive, one or two each year tend to stand out as captivating examples of applied optical microscopy. The one that I would like to present in this article (along with my intern for the project - Alvaro Galvis) is the early Catholic statues (santos) from Chihuahua, Mexico and southern California.

Santos (Fig. 1.) are statues of saints and other religious personalities common in Hispanic communities, world-wide. The santos from this study were constructed over 300 years ago by European craftsman and the Tarahumara at a time when the Jesuit missionaries were introducing Catholicism to Mexico. What makes the santos of this period unique is that the wood used for the arms and legs was very light and not recognized as a commercial timber. The samples of unknown identity were tentatively called "lightwood". Using a combination of light microscopy, ethnobotany, detective work and pure luck (serendipity), it is now known that the "lightwood" comes from the genus Erythrina. Commonly known as colorin or chilicote, the plants of this genus have been known to have both medicinal and religious value to the Tarahumara (Schultes and Hofmann, 1979). This "signature wood" in the santos of the Chihuahua Missions allows one to determine wnere me santos were created, and its presence in the santos of the Early California Missions elucidates their dissemination.

\section{Microscopical Wood analysis of Santos from Chihuahua mis- sions and from San Luis Rey mission in California}

Wood samples from santos were prepared by trimming each to expose the radial, tangential and transverse surfaces. For each of these surfaces, thin $(15-20 \mu \mathrm{m})$ sections are removed by hand with a singleedge razor blade. The sections are then mounted on labeled microscope slides in a 1:1 solution of ethanol and glycerin. Slides are heated briefly on a hot plate, to drive off air bubbles and then examined under a compound microscope. The results can be seen in Table 1 .

\begin{tabular}{lcc}
$\begin{array}{c}\text { Wood } \\
\text { Type }\end{array}$ & $\begin{array}{c}\text { Chihuahua } \\
\text { \% of samples }\end{array}$ & $\begin{array}{c}\text { San Luis Rey } \\
\text { \% of samples }\end{array}$ \\
\hline Basswood & 0.0 & 3.3 \\
Cedrela & 0.8 & 3.3 \\
Douglas Fir & 0.0 & 1.7 \\
Fir - European & 0.8 & 0.0 \\
Juniper & 1.6 & 1.7 \\
Erythrina & 14.3 & 25 \\
Mahogany & 0.0 & 3.3 \\
Pine (combined) & 71.4 & 36.7 \\
Populus & 0.8 & 0.0 \\
Sequoia & 0.8 & 0.0 \\
Unknown & 2.4 & 25.0 \\
Walnut & 1.6 & 0.0 \\
Willow & 5.6 & 0.0 \\
\hline Total Samples & 126 & 60 \\
\hline Total Santos & 65 & 28 \\
\hline
\end{tabular}

Table1. Percentage of wood types found in santos used in this study.

The main woods used in construction of the santos are pine (Pinus) and Erythrina. It appears that some of the santos may have been brought to North America from Europe, based on the woods used. I would
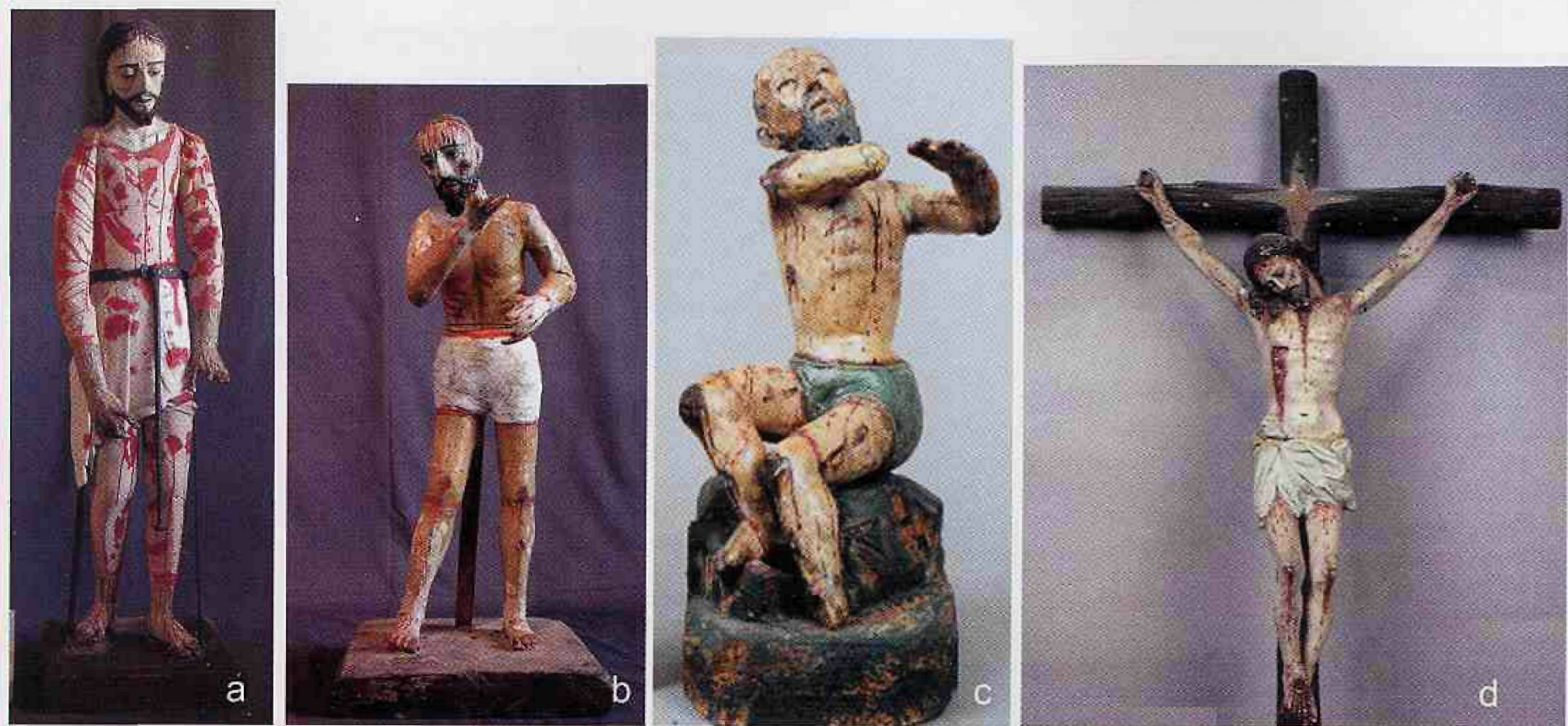

Figl. Four santos with arms and legs made of Erythrina (left two from the Chihuahua Missions, and the right two are from Mission San Luis Rey in California. 


\section{in your drive for excellence, get a little extra help...}

Today, it is no longer enough to make leading edge products.

Support, training, and top quality service are key elements of our unique solutions for microanalysis.

Before purchasing your next EDS, WDS or EBSD system, ask for your free guide to 'Microanalysis Explained', and see how Oxford Instruments can boost your drive to success.
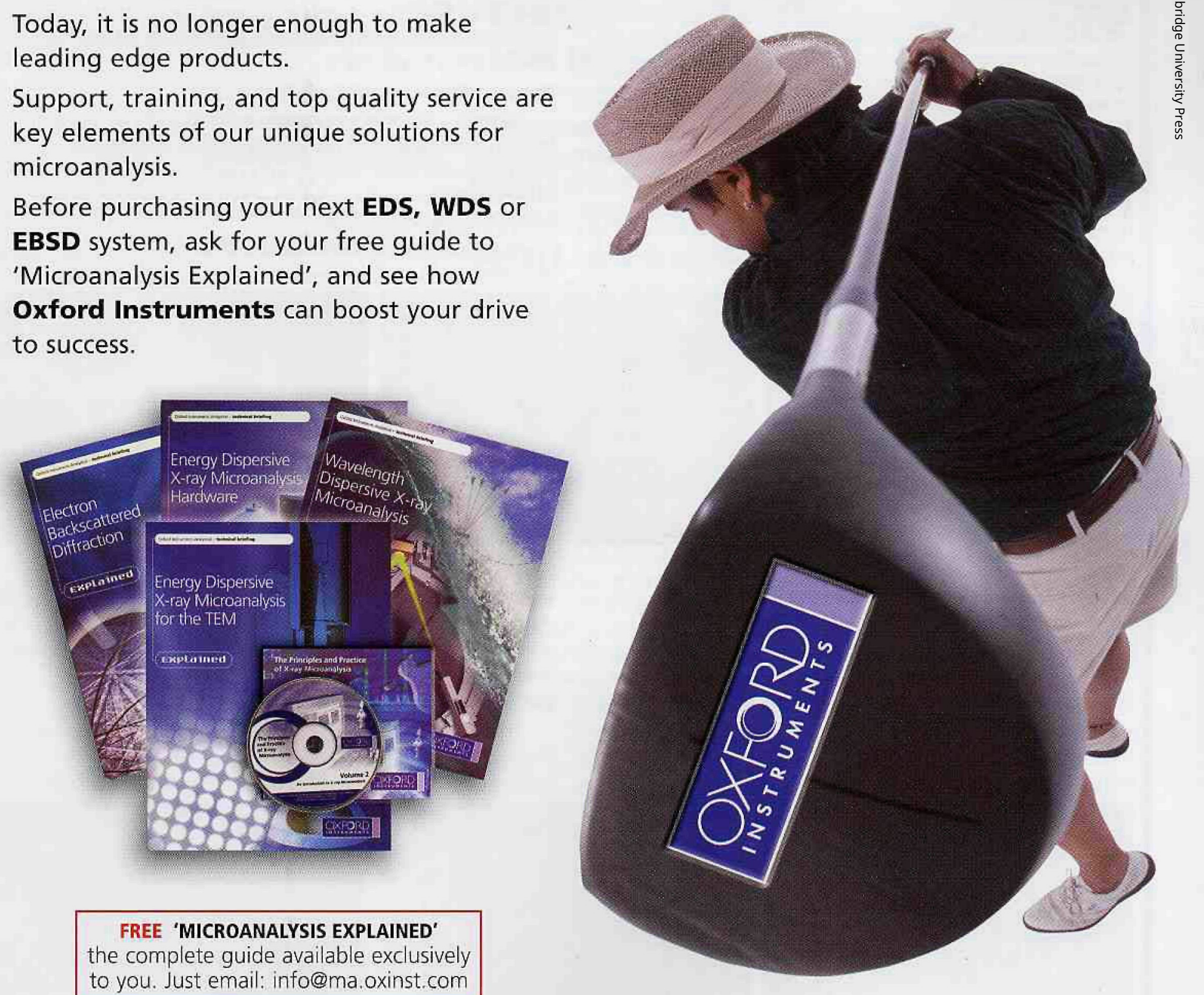

FREE 'MICROANALYSIS EXPLAINED'

the complete guide available exclusively to you. Just email: info@ma.oxinst.com 


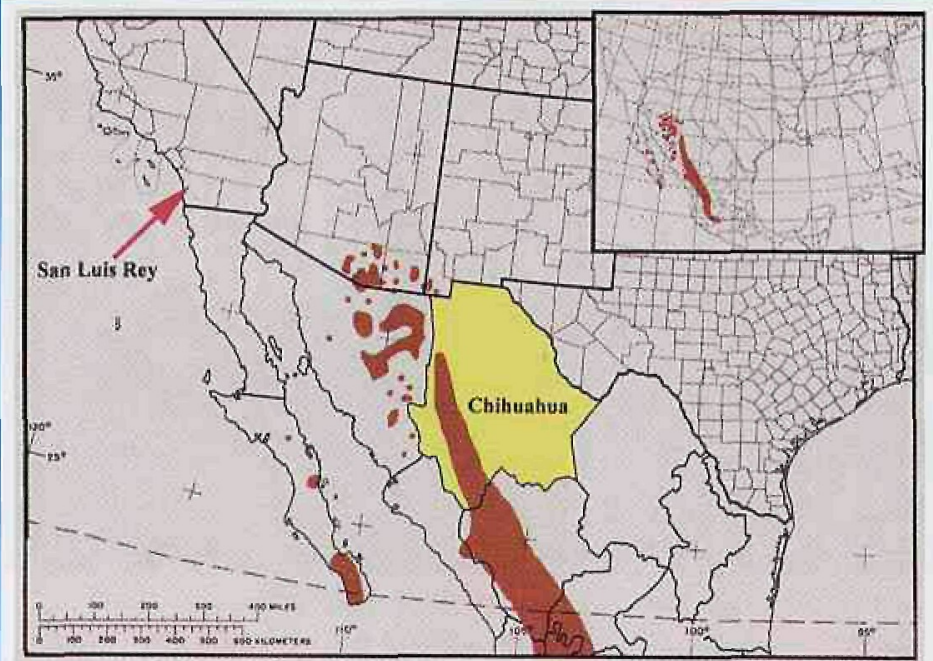

Fig2. Map of study area, showing the growth range of Erythrina flabelliformis (brown area), the state of Chihuahua (yellow) and the location of Mission San Luis Rey (arrow).

expect that the santos that are made of Basswood (Tilia sp.), Douglas Fir (Pseudotsuga menzeisii), European Fir (Abies sp.), and Sequoia (Sequoia sp.) are in this category because these woods are not native to northern Mexico or south western United States. The santos that contain Cedrela (Cedrela sp.), Juniper (Juniperus sp.), and Mahogany (Swietenia sp.) may also have been made elsewhere, but also may have been available to the Tarahumara. Juniper is a traditional wood used

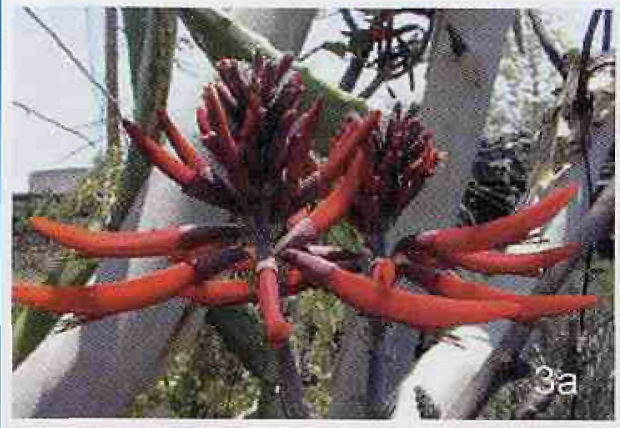

Fig3. Flowers of Erythrina flabelliformis.

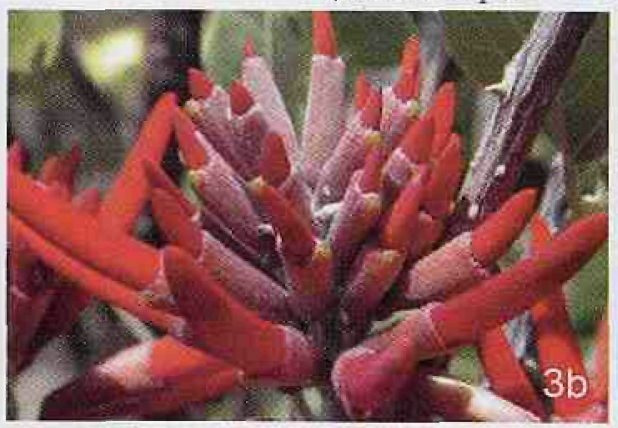

in religious objects from Europe and both Cedrela and Mahogany are the most common woods used for santos in the Caribbean.

\section{The genus Erythrina}

A genus belonging to the bean family (Fabaceae/Papilionoideae), Erythrina consists of 108 species of wide distribution in the tropical portions of the world (Schultes and Hofmann, 1980). In Mexico alone, there are 18 species of Erythrina, with only Colorin ( $E$. flabelliformis) being a large enough plant to be used for the construction of the arms

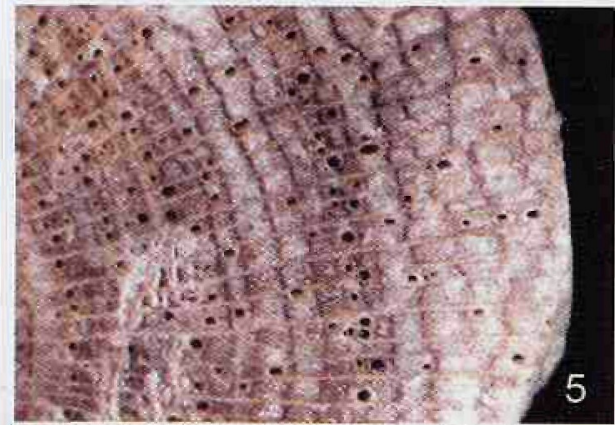

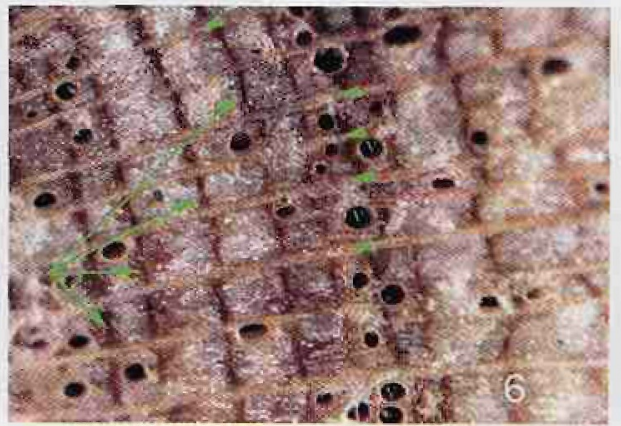

Fig6. Close-up of figure5, showing red fiber bands (arrows), vessels ( $V$ ) and rays (arrowheads). and legs of the santos. E. flabelliformis is native to central Mexico, southern Baja and the southern borders of Arizona and New Mexico. A large number of common, vernacular names are reported for $E$. flabelliformis from Mexico that includes the following: chak-mool-che, chijol, chilicote, chocolin, colorín, madre chontal, patol, pito, purenchequa and pureque (Standley, 1920; Martinez, 1969).

Erythrina flabelliformis are trees with spines on the branches and leaves that are pinnately compound (trifoliate). The brilliant, blood-red flowers are grouped together at the extremes of the branches (below), giving the plant an ostentatious appearance. The fruit of this plant is a pod with bright red, smooth seeds (Martinez, 1969; Standley, 1920)

The reddish beans of Erythrina are known to have poisonous properties and have been reported as hallucinogens by the Tarahumara. There is some confusion about the latter attribute, as the seeds resemble those of Mescal Bean (Sophora secundiflora), which are hallucinogenic. Both types of seeds are frequently interchangeable and are sold together in modern Mexican markets under the name colorínes. (Shultes, 1969; Merill, 1977).

\section{Optical microscopy of Erythrina}

Erythrina is not a commercial wood, but one species ( $E$. flabelliformis) is included as a minor western hardwood in Atlas of U.S. Trees, Volume 3 (Little, 1976). This appears to be the only species that grows large enough (and produce enough wood) to be a viable candidate for the appendages of the santos.

It is characterized by the abundance of parenchyma, like balsa (Ochroma sp.), but has intermittent fiber bands, storied parenchyma,

wide rays and numerous prismatic crystals and crystal sand in the storied parenchyma. All anatomical characters of the wood of the "lightwood" samples match those of Erythrina reported by Barajas-Morales \& Gomez (1989) and by Barajas-Morales, et al. (1997).

\section{The Role of Erythrina in the Tarahumara}

The use of Erythrina by the Tarahumara prior to the Jesuit missionaries is significant as the seeds have been found in burial sites inside storage vessels as possible burial offerings ( $\mathrm{Zingg,1940)}$ ). The wood.

Fig5. Macroscopic view of Erythrina

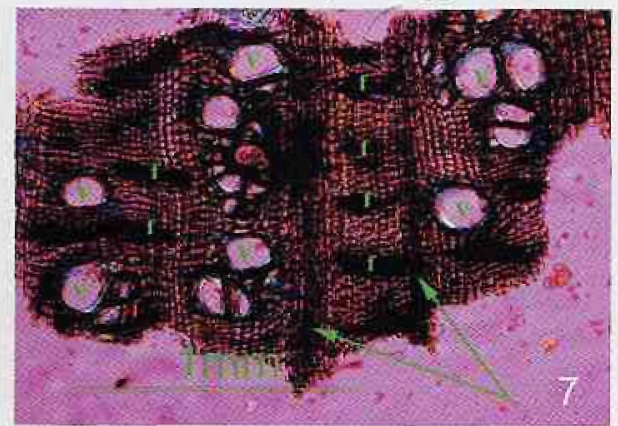

Fig7. Cross section of Erythrina sample, showing rays (arrows), vessels (V) and fiber bands $(f)$. 


\section{EDSS2004}

* NEW Architecture Featuring

Expect More from your EDS Company

Elo Wew Edt Setuo Acquire Procoss Parbile Andyds Properties Window Beb

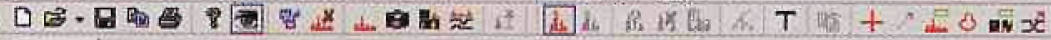

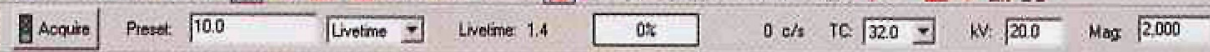

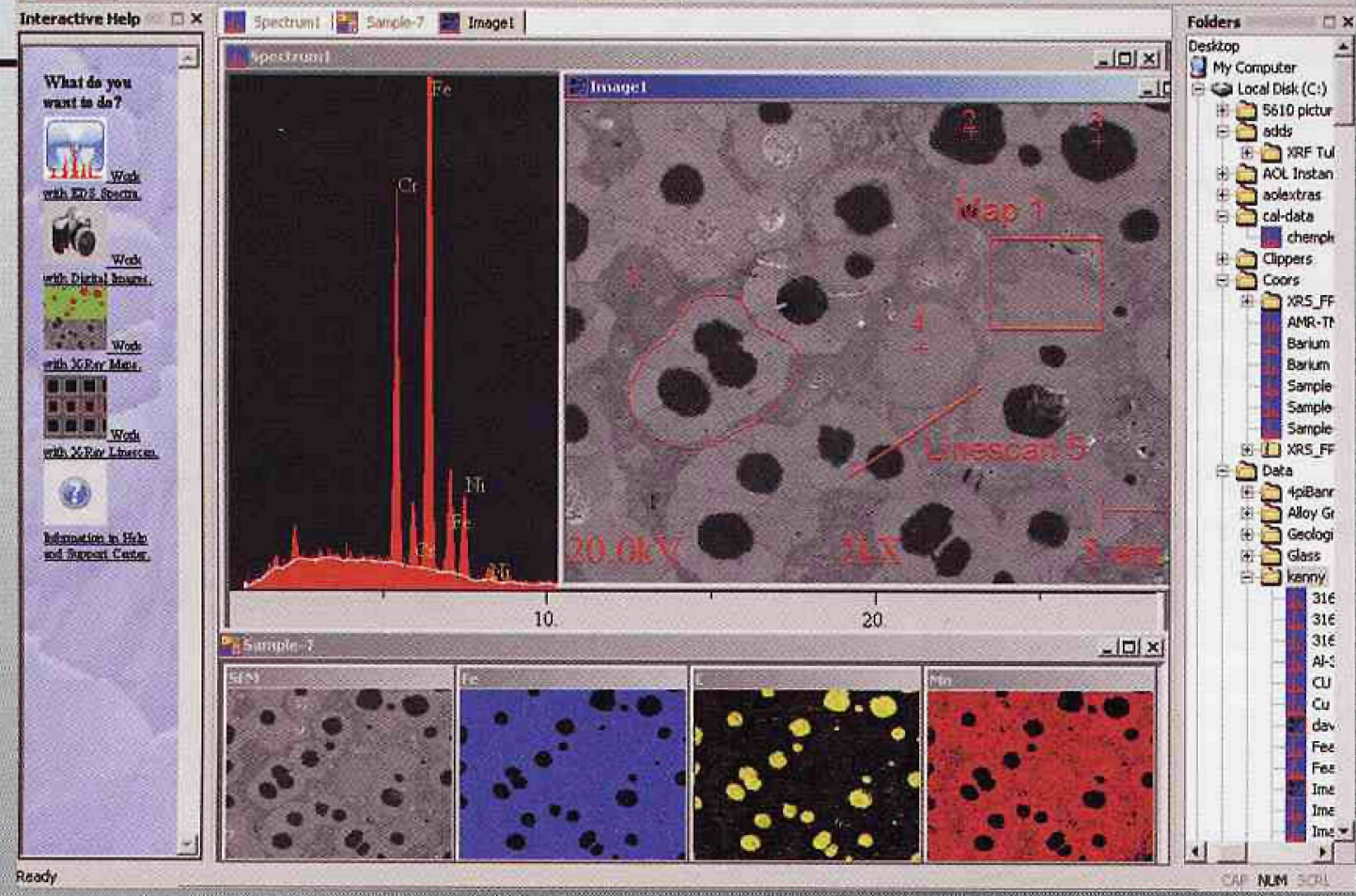

1

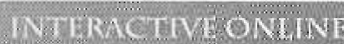

GUGG FERTURED, NO ADD-ONOPTION

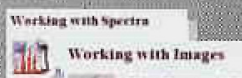

III

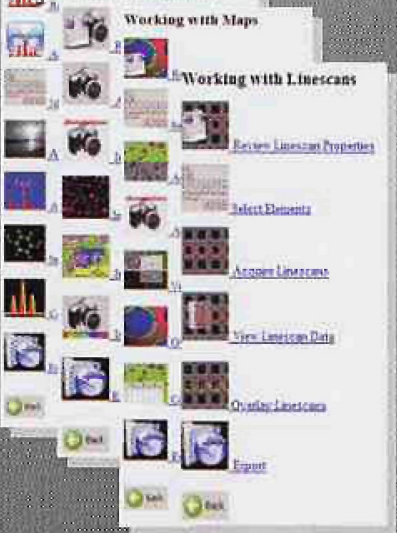

PDS2004 includes all of these features and more standaind. NOT as options

Fhid Resolution lmaging

Spectral Mappine

Automared Particle Analysis

Specimil Whiching

7. NF Quantiation

Interacilive Online Itelp

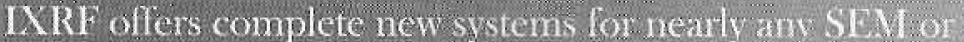
THM

and for upgrades, we can interlace to anv existing DDS defector.

FRED Solwware upgrade wa the mkemet for the Ha of the siviter:

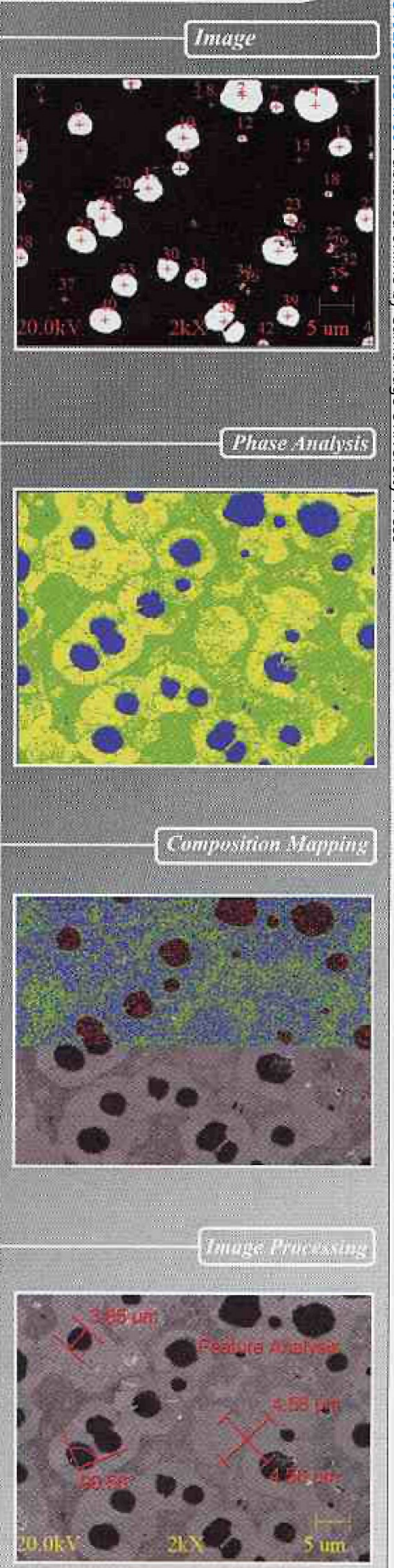

\section{Easi hinsorins}

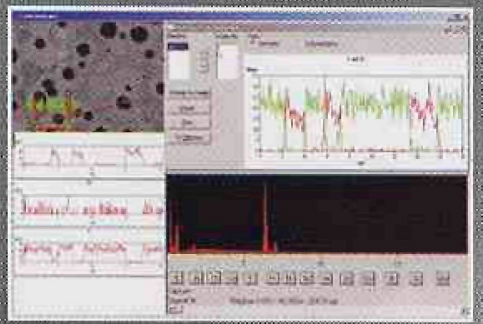

\section{Amomued Dartide andusis}

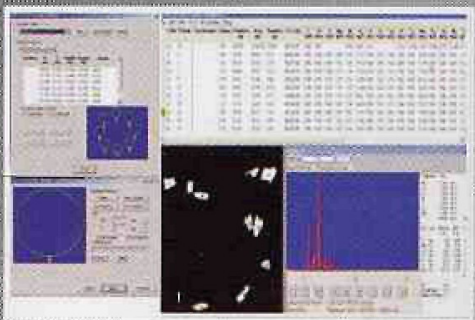

\section{Sheetra warcing?}

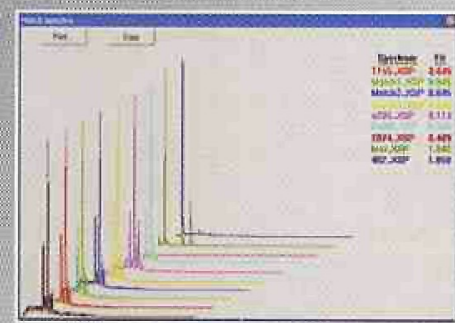

Free software upgrades mean you will never have to replace your system!

IXRF Systems 


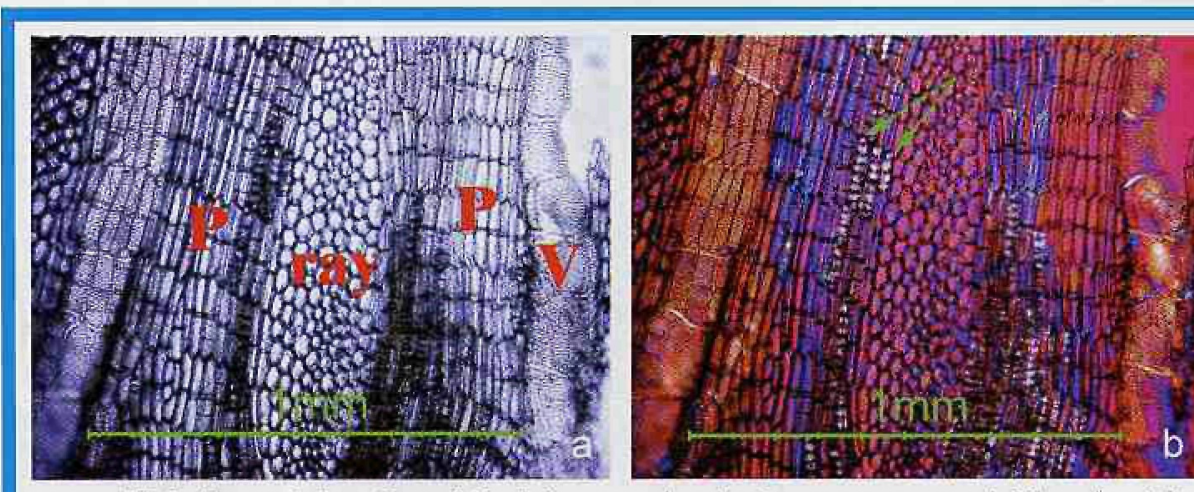

Fig8. Tangential section of Eryhrina sample, showing a ray, a vessel (V) and axial parenchyma $(P)$, in normal light $(l)$ and circular polarized light $(r)$.

red seeds of Erythrina, have been used to create necklaces and rosaries (Bye, 1978) These particular rosaries or necklaces are used in ceremonies performed after a family member has passed away. The seeds are also used as a form of protection, in particular for small children, as necklaces that have a cross or a medal of a Catholic saint (Merill, 1988). Medicinally, the red seeds have been employed cautiously by the Tarahumara to treat intestinal disorders, toothaches and as an emetic (Pennington, 1963. Bye, 1978. Schultes and Hofmann, 1980).

The use of Erythrina in the arms and legs of santos may be due to replacing of broken appendages. Arms, legs and other protrusions from the statues (staffs, banners, etc.) are usually the first parts of the santos to become broken. I feel that the choice of Erythrina wood was intentional. Other woods like Cedar (Juniperus sp.), Willow (Salix sp.) and Cottonwood (Populus sp.) may have been available to the Tarahumara. These woods are easily carved and are stronger and more durable than Erythrina. Many of the santos constructed with wood from Erythrina are painted with bloody wounds. There may be more than a symbolic coincidence between the blood streams and the deep red flowers of Erythrina.

\section{Conclusion}

The Tarahumara have had a long history in using Erythrina both for its medicinal properties and its religious values. The use of Erythrina wood in santos may be a case of cultural blending, either blatant or secretive, where the raw materials of their aboriginal cultural icons were incorporated into Catholic santos. This would allow the Tarahumara to accept Catholicism without abandoning their cultural "roots" so to speak. Alternatively, the Tarahumara were forced to accept Catholicism by the Spanish and thus like many other native peoples, were forced to hide their traditional beliefs. The santos provided such a tool. Santos were seen as protectors by the Tarahumara. In the eyes of the missionaries the natives seemed to be converting to Catholicism, but in reality were worshiping their traditional protector, Erythrina.

\section{Acknowledgements}

We are greatly indebted to Karla MunozAlcocer for collecting the wood samples from santos of the missions in Chihuahua, Mexico and Mission San Luis Rey in California. We also want to thank her for her interaction with the Tarahumara, who suggested that we investigate the use of Erythrina and for her assistance in
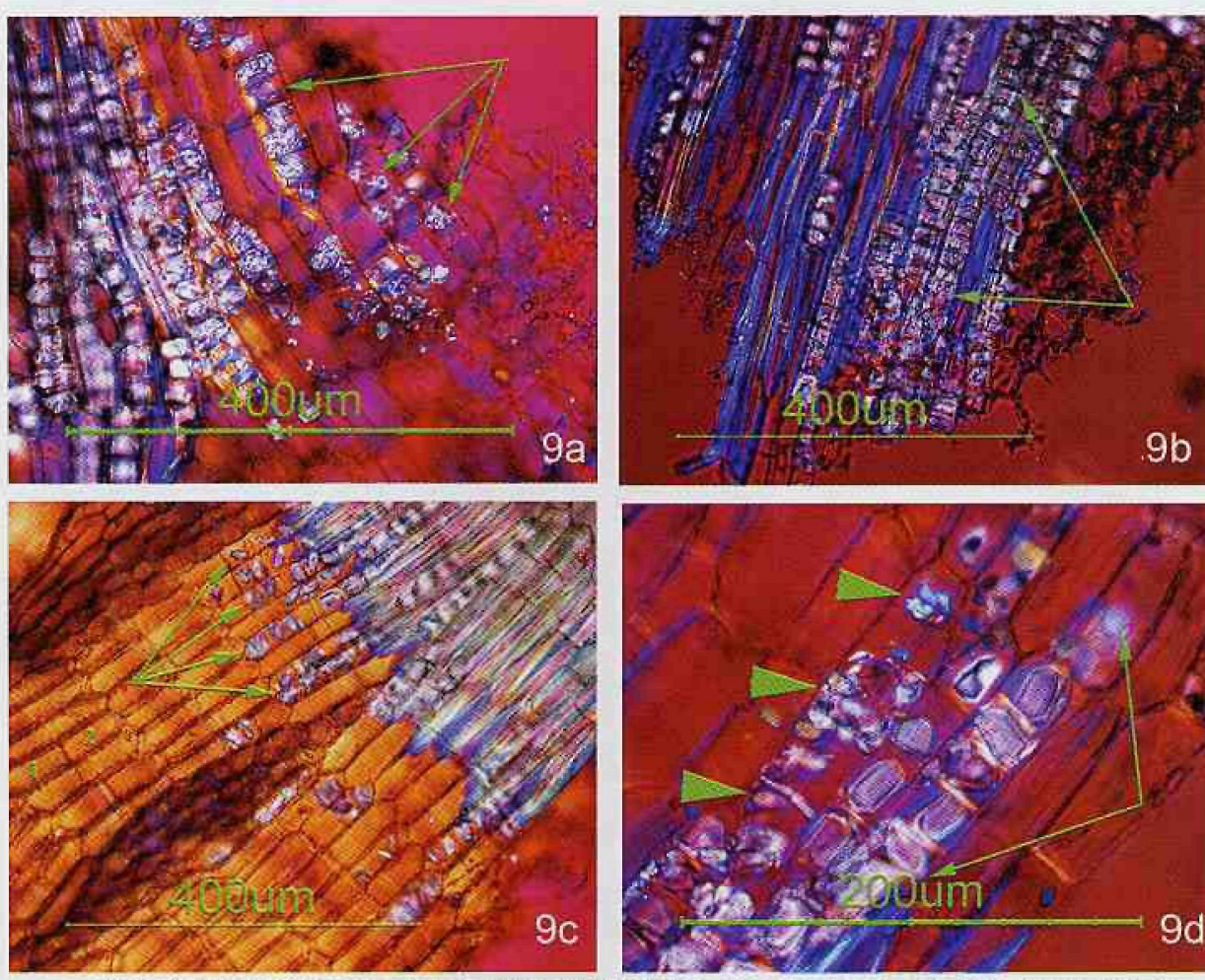

Fig9. Radial and tangential sections of Erythrina, showing large numbers of crystals in parenchyma cells (arrows) using circular polarized light ( $\lambda$ plate). Most of the crystals are prismatic in long chains (arrows), with others being smaller "crystal sand" type (arrowheads). 
iit:-

$\therefore$

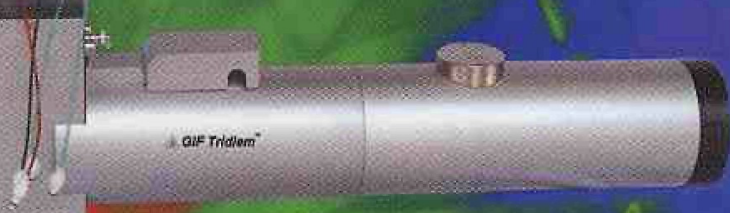

GIF TRIDIEM

THE NEXT GENERATION IMAGING FILTER HAS ARRIVED

MonoCL

one sdan...one data set...

YOUR CL RESULTS

\section{Uitrascan}

defining inage resolution

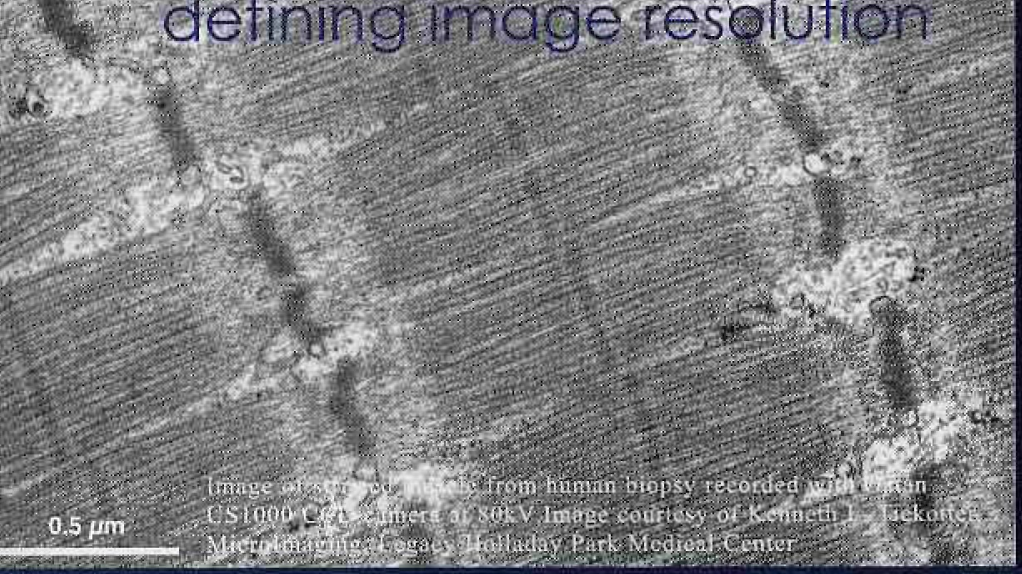

t)

Specinge
Holde

optimized for

tomography

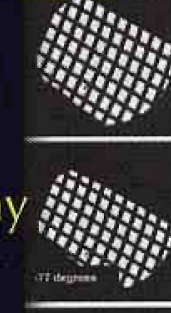

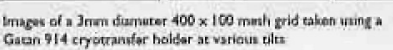
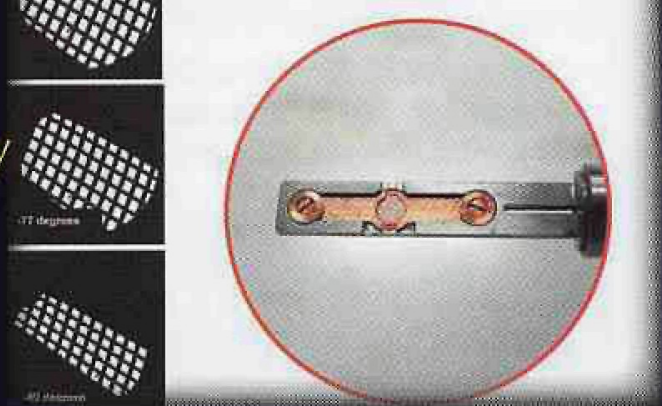

PRECIS I O N

P R O D U C T I V I T Y

\section{PERFORMANCE}

